\title{
Body Image and Eating Behaviors among El-Minia University Students
}

\author{
Hassan , Z., M ; Ewis , A., A ; Hossein , Y., El.S ; Mahmoud , S ., R. \\ Public Health and Community Medicine Dept., Faculty of Medicine El-Minia University. \\ Community Health Nursing Dept., Faculty of Nursing Assiut University. \\ Community Health Nursing Dept., Faculty of Nursing El-Minia University.
}

\begin{abstract}
:
body image and eating behavior have been major concern for adulthood especially among college students. In this study, we aimed to know body image concern among college students and assess the relationship between body image and eating behavior among university students. Subjects and Methods: cross-sectional study of 495 male and female students enrolled in first and fourth grade from practical and non practical faculties randomly selected completed a questionnaire consisting of socio-demographic characteristics, Eating Attitude Test (EAT-26), Body Shape Questionnaire (BSQ-34) and Body Figure Rating Scale (BFRS). Results: The majority of male and female students have normal weight and average body mass index, Females choose (thin figure, very thin and below average, respectively) as a current shape which represent their body shape. While males choose shape (below average and thin figure) as current shape. Females were significantly more feeling anxious, overweight, and concerned about their body shape than males ( $\mathrm{p}=0.001,0.01$ and 0.04 , respectively). Conclusions: Based on the results of the present study, it was concluded that about more than half of participants have normal weight according BMI. The present study found that females were more concerned about their body shape more than males. Body shape concerns among females were associated with anxiousness, feeling overweight, and preoccupation with food and purging behavior. Recommendations: health education about body image and its effect on psychological status and eating behaviors of the students and how to deal with negative body image.
\end{abstract}

Key words: Body Image, Eating Behavior and College Students.

\section{Introduction:}

The concept of body image combines all elements of people's mental self-image (including perception, thought, feelings, and attitudes), evaluation of their physical image and the effect of this image on their behavior (DiGioacchino et al., 2001). Also, Body image may be defined in simple terms as the way a person perceives or thinks about his body and how it appears to others (Khor et al., 2009).

Body image has cognitive, affective, perceptual and behavioral components. The cognitive aspect of body image involves individuals' thoughts about their body (e.g., body dissatisfaction). The affective component of body image involves individuals' feelings about their body (e.g., body shame and appearance anxiety). The perceptual aspect of body image refers to individuals' judgments of their body size compared to the actual body size. Finally the behavioral aspect of body image (such as avoidance of situation where the body will be exposed) (Barlett and Harris, 2008; Banfield and McCabe, 2002).

Body image is the aspect of the self-concept that begins to develop in the earliest stages of awareness of self. It has the physical body focus, and other aspects of self concept are elaborated around it. An individual attitude toward the body may mirror important aspect of their identity. A person feeling that the body is big or small, attractive or unattractive, weak or strong also reveals some thing about their self concept (Sheild, 2004).

A number of studies have shown that body image concern is associated with chronic dieting, unhealthy weight control behaviors, poor self-esteem, depression, and the development of eating disorders (Cheung, 2007).

Eating behaviors refer to all actions or activities (cognitive, motor, emotional and social) undertaken by individual (child, adolescent, and adult) in relation to food and body weight in order to adapt to the environment, satisfy his needs and solve his problem (National Eating Disorder Association, 2001).

The transition to college is considered to be a particularly high-risk period for the development of eating disorders. Unhealthy eating practice among college students may be linked to new experiences faced at college, high academic demands, and a lack of predictability in the student's daily life (Delinsky et al., 2007).

College students also have to maintain a full course load, which includes many late night study sessions and the accumulated stress of assignments and exams. Some may even have to hold part-time jobs to be able to afford to attend college. Also, college years are generally the first time that students living away from home are faced with many different food choices. Most students are transitioning to 
independent living and, therefore, are making their own choice on what to eat, which often results in poor diet and eating choices (Brunt et al., 2008)

The most prevalent common eating behaviors Fast food: Fast foods are quick, reasonable price, and readily available alternative cooking, (Carling, 2006). Dieting is the practice of eating food in a regulated fashion to achieve or maintain a controlled weight (Smith, 2004). A snack is a portion of food oftentimes smaller than that of a regular meal that is generally eaten between meals (Sebastian, et al., 2008). Vegetarianism encompasses the practice of following plant-based diets (fruits, vegetables, cereals, legumes and nut), with or without the inclusion of dairy products or eggs, and with the exclusion of meat (red meat, poultry, and seafood) (Journal of American Dietetic Association and Dietitians of Canada, 2003).

Body image perception varies greatly among males and females within the same age group. In recent years, several studies have concluded that females have a higher tendency to adjudge themselves as not conforming to weight ideals as compared to men (Cheung, 2007).

Eating disorders refer to a group of conditions defined by abnormal eating habits that may involve either insufficient or excessive food intake to the detriment of an individual's physical and mental health. Bulimia nervosa, anorexia nervosa, and binge eating disorder are the most common specific forms in the United States (Hudson, et al., 2007).

In U.S. about 5-10 million of females affected with eating disorder and about one million of males affected (Hudson et al., 2007). The National Eating Disorders Association reported that women outnumbered men 10 to 1 in reported cases of eating disorders such as bulimia and anorexia nervosa (National Eating disorders Association, 2005).

\section{Subjects and methods:}

Research design:

Cross-sectional research design was used

\section{Setting :}

El-Minia University includes (16) faculties. These faculties were categorized into two groups. Group 1 included eight practical faculties and group 2 included the rest 8 non-practical "theoretical" faculties. Four faculties from each group were selected randomly. The selected practical faculties included "Pharmacy, Medicine, Engineering and Nursing" and the selected four theoretical faculties included "Arts, Tourism, Linguistics and Dar ElOlom ".

\section{Sample:}

Sample size was calculated according to the equation for the sample size of descriptive study design

$\mathbf{N}=(\mathbf{Z} \text { 1- } \alpha / 2)^{\mathbf{2}} \mathbf{P}(\mathbf{1 - P}) / \mathbf{D}^{\mathbf{2}}$

$\mathrm{N}=$ Sample size

$(\mathrm{Z} 1-\alpha / 2)^{2}=$ Represent the number of standard from the mean

$\mathrm{P}=$ Represent the proportion of the best guess about the value of the proportion of interest

$\mathrm{D}=$ The absolute precision required on either side of the proportion, or the distance; how close to the proportion of interest the estimate is desired to be.

Note:-

In this study, we considered that:-

Confidence level $=95 \%$

$$
\mathrm{P}=0.50
$$

$\mathrm{D}=0.05$

$(1-\mathrm{P})=0.50$

$(\mathrm{Z} 1-\alpha / 2)^{2}=1.96$

$\mathbf{N}=3.8416 \times 0.50(0.50) / \mathbf{0 . 0 0 2 5}=384$

The result is 479 students. The sample size was raised to 495 students to safe guard against any drop outs or missing items of the questionnaires and get more informative results.

\section{Study population and sampling:}

Study population included 9509 students in 1st and 4 th year of education. The total sample was distributed among practical and theoretical faculties as follows.

\begin{tabular}{|l|c|c|}
\hline \multicolumn{1}{|c|}{ Faculty name } & Total No & Sample No \\
\hline Pharmacy & 601 & 30 \\
\hline Medicine & 594 & 30 \\
\hline Nursing & 249 & 12 \\
\hline Engineering & 957 & 48 \\
\hline Fine Arts & 164 & 8 \\
\hline Tourism & 1655 & 83 \\
\hline Linguistics & 650 & 33 \\
\hline Dar El-Olom & 4639 & 232 \\
\hline \multicolumn{1}{|c|}{ Total No } & $\mathbf{9 5 0 9}$ & $\mathbf{4 7 6}$ \\
\hline
\end{tabular}

\section{Tools of the study:}

Tool 1:

This tool was formed to collect personal and physical data about all students enrolled in the study as: age, sex, weight, height, and the academic year. Body Mass Index (BMI) was calculated as weight in $\mathrm{kg} / \mathrm{m}^{2}$ using the following equation $\mathrm{BMI}=$ weight $(\mathrm{kg}) /$ height $(\mathrm{m})^{2}$ and classified according to World Health Organization (WHO, 2006; CDC, 2011)

- Underweight (BMI $<18.5 \mathrm{~kg} / \mathrm{m}^{2}$ ).

- Normal weight (BMI 18.5-24.9 kg/m²).

- Overweight (BMI 25-29.9 kg/m²).

- Obese (BMI >30 kg/m²). 
Tool 2:Eat-26 scale was developed by (Garner and Garfinkel, 1979). It was modified by (Garner,et al ., 1982):- this test used to investigate the eating disturbance and the risk of developing an eating disorder. The EAT-26 scale include four domains It was scored using a rating scale with a choice of three modified answers:

"always", "sometimes", and "never" for each of the 26 statements.

The four domains are:

1. Dieting behaviors were measured by 32 items.

2. Oral control and bulimia were measured by 29 items.

3. Food preoccupation was measured by 31 items.

4. Purging behaviors were measured by 29 items.

\section{Scoring System:}

The response of "always", "sometimes", or "never" were scored 3, 2, 1 respectively for positive items and scored 1, 2, 3 respectively for negative items. The scoring systems were judged as.

Poor eating or weight concerns ....... » 26- 49

Average eating or weight concern... » 50-59

Serious eating or weight concerns ... » 60- 78

Tool 3:-

The body shape questionnaire (BSQ) was developed by Cooper et al., (1986):- The BSQ consists of 34 items used to assess body shape concerns and level of preoccupation with weight and body shape.

It was scored using a rating scale with a choice of three modified answers:

"always", "sometimes", and "never" for each of the 34 statements.

The four domains are:

1. Other's opinions was measured by 38 items.

2. Body shape dissatisfaction was measured by 26 items.

3. Body shape anxiousness was measured by 39 items.

4. Feeling over weight was measured by 21 items.

\section{Scoring System:}

The response of "always", "sometimes", "never" were scored 3, 2, 1 respectively for positive items and scored 1,2, 3 respectively for negative items. The scoring systems were judged as.

Poor concern with body shape ........ $\gg$ 34- 51

Average concern with body shape... » 52- 85

Marked concern with body shape ... » 86- 102

Tool 4:-

Body Figure Rating Scale (BFRS) this scale was developed by Fallon and Rozin (1985):- It consisted of 9 figures drawing representing the front view outlines of somatotype photographs for females and other 9 for males, ranging from "extremely thin" to "extremely fat". Subjects were asked to choose the figures drawing they felt looked most like them and which one they liked most to resemble (current).
They were also asked to choose which of the figures they would most like to look like (ideal), the figures most attractive to other sex (attractive), and finally, the figure of the opposite sex they found most attractive (other attractive).

Figures were scored on a 9-point scale (1= extremely thin figure and $9=$ extremely fat).

\section{Methods:}

\section{1-Preparatory phase:}

Before the conduction of the study, an official letter was taken from the dean of the faculty of Nursing at El-Minia University to the Dean of each of the randomly selected faculties. After a brief explanation of the purpose of the study, a written permission was secured to the Dean of each faculty in the study sample. Each student was assured that the information obtained confidential and will be used for the purpose of the study. Numbers of the students in the university were obtained from EL-Minia University Management Information Systems.

\section{2-Pilot study:}

A pilot study was carried out after the development of the study tools, and before the data collection phase. It was carried out on ten students of the study. This number was in study sample.

\section{3-Ethical considerations:}

Oral consent was taken from every student; data was collected through interviewing the students individually, and reassured that the information obtained will be confidential and used only for the purpose of the study.

\section{4- Data collection:}

Subjects were chosen from first and fourth grade by systematic random sampling of each faculty. The masters of each grade were informed that the study concerned body image and eating behaviors among college students and those participants would be fill in confidential questionnaires that will take 15-20 minutes to be completed. The researcher was introduced to the students by the masters. We explained the purpose of the study and how to complete the questionnaires. Participants were collectively informed of their right not to participate in the study. Tools were distributed to students in small group settings ranged between 20-25 students under our observation and they collected immediately after they were completed.

The researchers visited each chosen faculty according to time available for it, (some faculties need more than three days according to type and number of students in the faculties). This phase of data collection started from 15 October 2011 to 30 December 2011.

\section{5-Statistical design:}


Data collected, coded, and verified before data entry and then all data were computerized, revised, categorized, tabulated, and analyzed by using computer program Statistical Package of Social Science (SPSS V11.5). Using descriptive statistics in the form of frequencies and percentages, as well as mean and standard deviations. Qualitative variables were compared using Chi-squared test and quantitative variables were compared using test. For nonparametric comparisons Mann Whitney test. Statistical significance was considered at $\mathrm{p}$-value $<0.05$.

\section{Results:}

Table (1): Distribution of the studied students according to their personal and physical characteristics, ElMinia university, $2011(\mathrm{n}=495)$.

\begin{tabular}{|c|c|c|c|c|}
\hline \multirow[t]{2}{*}{ Personal and physical characteristics } & \multicolumn{2}{|c|}{ First grade } & \multicolumn{2}{|c|}{ Fourth grade } \\
\hline & $\mathrm{No}=246$ & $\%$ & No $=249$ & $\%$ \\
\hline $\begin{array}{c}\text { Age (years) } \\
18-20 \mathrm{y} \\
21-26 \mathrm{y}\end{array}$ & $\begin{array}{l}239 \\
7\end{array}$ & $\begin{array}{l}97.2 \\
2.8\end{array}$ & $\begin{array}{l}133 \\
116\end{array}$ & $\begin{array}{l}53.4 \\
46.6\end{array}$ \\
\hline Mean \pm SD & \multicolumn{2}{|c|}{$18.64 \pm 0.73$} & \multicolumn{2}{|c|}{$20.58 \pm 1.04$} \\
\hline $\begin{array}{l}\text { Sex } \\
\text { Male } \\
\text { Female } \\
\end{array}$ & $\begin{array}{l}140 \\
106 \\
\end{array}$ & $\begin{array}{l}56.9 \\
43.1 \\
\end{array}$ & $\begin{array}{l}123 \\
126 \\
\end{array}$ & $\begin{array}{l}49.3 \\
50.6 \\
\end{array}$ \\
\hline $\begin{array}{l}\text { Faculty } \\
\text { Nursing } \\
\text { Medicine } \\
\text { Engineering } \\
\text { Pharmacy } \\
\text { Dar El-Oloum } \\
\text { Arts } \\
\text { Linguistics } \\
\text { Tourism } \\
\end{array}$ & $\begin{array}{l}8 \\
15 \\
23 \\
18 \\
112 \\
32 \\
34 \\
4 \\
\end{array}$ & $\begin{array}{l}3.3 \\
6.1 \\
9.3 \\
7.3 \\
45.5 \\
13.0 \\
13.8 \\
1.6 \\
\end{array}$ & $\begin{array}{l}8 \\
15 \\
25 \\
15 \\
119 \\
17 \\
45 \\
5 \\
\end{array}$ & $\begin{array}{l}3.2 \\
6.0 \\
10.0 \\
6.0 \\
47.8 \\
6.8 \\
18.1 \\
2.0 \\
\end{array}$ \\
\hline $\begin{array}{l}\text { Body Mass Index }\left(\mathbf{K g} / \mathbf{m}^{2}\right) \\
\text { Under weight } \\
\text { Normal weight } \\
\text { Over weight } \\
\text { Obese }\end{array}$ & $\begin{array}{l}2 \\
204 \\
30 \\
10\end{array}$ & $\begin{array}{l}0.8 \\
83.0 \\
12.2 \\
4.0\end{array}$ & $\begin{array}{l}2 \\
173 \\
28 \\
23\end{array}$ & $\begin{array}{l}0.8 \\
69.5 \\
11.2 \\
9.2\end{array}$ \\
\hline
\end{tabular}

Figure (1): Distribution of male and female according to BMI, El-Minia university, 2011 (n=495)

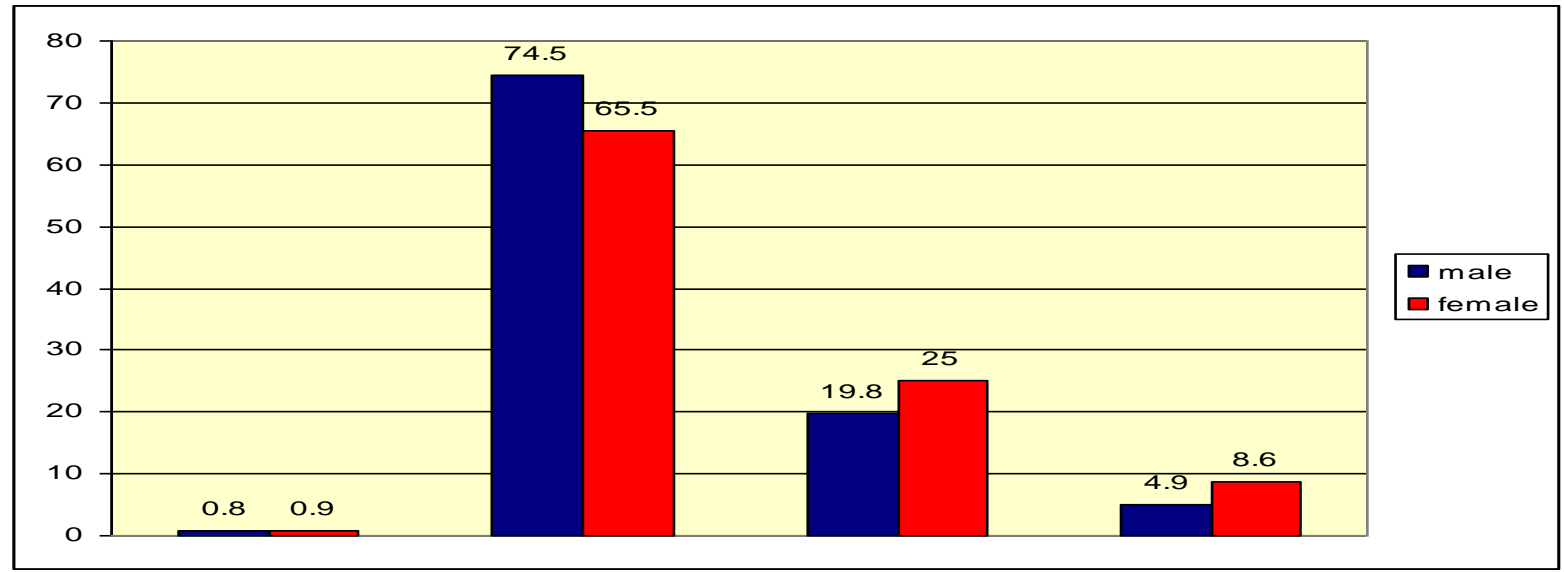


Table (2): Distribution of the studied students regarding their response to the body figure rating scale in relation to their sex, El Minia university, $2011(n=495)$.

\begin{tabular}{|c|c|c|c|c|c|c|c|c|}
\hline \multirow{3}{*}{ Body figure rating scale } & \multicolumn{4}{|c|}{ sex } & \multirow{3}{*}{$\begin{array}{l}\text { No } \\
(\mathbf{4 9 5})\end{array}$} & \multirow{3}{*}{$\begin{array}{l}\% \text { of } \\
\text { total }\end{array}$} & \multirow{3}{*}{$\mathbf{X}^{2}$} & \multirow{3}{*}{ P-value } \\
\hline & \multicolumn{2}{|c|}{$\begin{array}{c}\text { Males= } \\
(\mathbf{2 6 3})\end{array}$} & \multicolumn{2}{|c|}{$\begin{array}{c}\text { Females }= \\
(232)\end{array}$} & & & & \\
\hline & No & $\%$ & No & $\%$ & & & & \\
\hline Current shape & & & & & & & & \\
\hline Very thin & 46 & 17.5 & 57 & 24.6 & 103 & 20.8 & 10.6 & 0.15 \\
\hline Thin & 75 & 28.5 & 71 & 30.6 & 146 & 29.5 & & \\
\hline Below average & 79 & 30 & 53 & 22.8 & 132 & 26.7 & & \\
\hline Average & 48 & 18.3 & 41 & 17.7 & 89 & 18.0 & & \\
\hline Above average & 15 & 5.7 & 10 & 4.3 & 25 & 5.0 & & \\
\hline Ideal wished shape & & & & & & & & \\
\hline Very thin & 26 & 9.9 & 39 & 16.8 & 65 & 13.1 & 33.1 & $0.001 *$ \\
\hline Thin & 58 & 22.1 & 85 & 36.6 & 143 & 28.9 & & \\
\hline Below average & 113 & 43 & 85 & 36.6 & 198 & 40.0 & & \\
\hline Average & 60 & 22.8 & 19 & 8.2 & 79 & 16.0 & & \\
\hline Above average & 6 & 2.3 & 4 & 1.7 & 10 & 2.0 & & \\
\hline $\begin{array}{l}\text { What is the attractive shape to } \\
\text { you? }\end{array}$ & & & & & & & & \\
\hline Very thin & 27 & 10.3 & 30 & 12.9 & 57 & 11.5 & 9.3 & 0.23 \\
\hline Thin & 66 & 25.1 & 69 & 29.7 & 135 & 27.3 & & \\
\hline Below average & 96 & 36.5 & 71 & 30.6 & 167 & 33.7 & & \\
\hline Average & 64 & 24.3 & 50 & 21.5 & 114 & 23.0 & & \\
\hline Above average & 10 & 3.8 & 12 & 5.2 & 22 & 4.5 & & \\
\hline $\begin{array}{l}\text { What is the shape do you think } \\
\text { that it attracts the opposite sex }\end{array}$ & & & & & & & & \\
\hline Very thin & 9 & 3.4 & 43 & 18.5 & 52 & 10.5 & 41.4 & $0.001 *$ \\
\hline Thin & 81 & 30.8 & 79 & 34.1 & 160 & 32.3 & & \\
\hline Below average & 94 & 35.7 & 61 & 26.3 & 155 & 31.3 & & \\
\hline Average & 74 & 28.1 & 41 & 17.7 & 115 & 23.3 & & \\
\hline Above average & 5 & 1.9 & 8 & 3.4 & 13 & 2.6 & & \\
\hline
\end{tabular}

**Statistically Significant $p<0.05$

Table (3): Distribution of the studied students regarding their response to the body figure scale in relation to their BMI, El Minia university, 2011 (n=495).

\begin{tabular}{|c|c|c|c|c|c|c|c|c|c|c|}
\hline \multirow{3}{*}{ body figure rating scale } & \multicolumn{8}{|c|}{ BMI } & \multirow{3}{*}{$\mathbf{X}^{2}$} & \multirow{3}{*}{$\mathbf{P}$} \\
\hline & \multicolumn{2}{|c|}{ Under wt } & \multicolumn{2}{|c|}{ Normal wt } & \multicolumn{2}{|c|}{ Over wt } & \multicolumn{2}{|c|}{ obese } & & \\
\hline & No & $\%$ & No & $\%$ & No & $\%$ & No & $\%$ & & \\
\hline Current shape & & & & & & & & & & \\
\hline Very thin & 2 & 0.4 & 97 & 19.9 & 3 & 0.6 & 1 & 0.2 & & \\
\hline Thin & 2 & 0.4 & 120 & 24.6 & 22 & 4.5 & 2 & 0.4 & & \\
\hline Below average & 0 & 0.0 & 85 & 17.4 & 38 & 7.8 & 4 & 0.8 & 157 & $0.001 *$ \\
\hline Average & 0 & 0.0 & 40 & 8.2 & 34 & 7.0 & 14 & 2.9 & & \\
\hline Obese & 0 & 0.0 & 6 & 1.2 & 7 & 1.4 & 11 & 2.2 & & \\
\hline Ideal wished shape & & & & & & & & & & \\
\hline Very thin & 0 & 0.0 & 42 & 1.4 & 20 & 4.1 & 3 & 0.6 & & \\
\hline Thin & 1 & 0.2 & 97 & 19.9 & 31 & 6.4 & 12 & 2.5 & 25.32 & 0.12 \\
\hline Below average & 2 & 0.4 & 148 & 30.3 & 37 & 7.6 & 9 & 1.8 & & \\
\hline Average & 1 & 0.2 & 56 & 11.5 & 15 & 3.1 & 5 & 1.0 & & \\
\hline Obese & 0 & 0.0 & 5 & 1.0 & 1 & 0.2 & 3 & 0.6 & & \\
\hline
\end{tabular}




\begin{tabular}{|c|c|c|c|c|c|c|c|c|c|c|}
\hline \multirow{3}{*}{ body figure rating scale } & \multicolumn{8}{|c|}{ BMI } & \multirow{3}{*}{$\mathbf{X}^{2}$} & \multirow{3}{*}{$\mathbf{P}$} \\
\hline & \multicolumn{2}{|c|}{ Under wt } & \multicolumn{2}{|c|}{ Normal wt } & \multicolumn{2}{|c|}{ Over wt } & \multicolumn{2}{|c|}{ obese } & & \\
\hline & No & $\%$ & No & $\%$ & No & $\%$ & No & $\%$ & & \\
\hline \multicolumn{11}{|l|}{$\begin{array}{l}\text { What is the attractive } \\
\text { shape to you? }\end{array}$} \\
\hline Very thin & 0 & 0.0 & 35 & 7.1 & 17 & 3.5 & 5 & 1.0 & & \\
\hline Thin & 1 & 0.2 & 92 & 18.9 & 33 & 6.8 & 9 & 1.8 & & \\
\hline Below average & 2 & 0.4 & 129 & 26.4 & 27 & 5.5 & 7 & 1.4 & 18.03 & .65 \\
\hline Average & 1 & 0.2 & 76 & 15.6 & 26 & 5.3 & 8 & 1.6 & & \\
\hline Obese & 0 & 0.0 & 16 & 3.3 & 1 & 0.2 & 3 & 0.6 & & \\
\hline \multicolumn{11}{|l|}{$\begin{array}{l}\text { What is the shape do } \\
\text { you think that it attracts } \\
\text { the opposite sex? }\end{array}$} \\
\hline Very thin & 0 & 0.0 & 43 & 8.8 & 6 & 1.2 & 2 & 0.4 & & \\
\hline Thin & 1 & 0.2 & 116 & 23.8 & 29 & 5.9 & 14 & 2.9 & & \\
\hline Below average & 2 & 0.4 & 104 & 21.3 & 37 & 7.6 & 9 & 1.8 & & \\
\hline Average & 1 & 0.2 & 78 & 16.0 & 28 & 5.7 & 5 & 1.0 & 15.1 & 0.82 \\
\hline Obese & 0 & 0.0 & 7 & 1.4 & 4 & 0.8 & 2 & 0.4 & & \\
\hline
\end{tabular}

$*$ Statistically Significant $p<0.05$

Table (4): Total mean rank score of eating attitude test according to personal and physical characteristics of the studied university students, El-Minia university, $2011(n=495)$.

\begin{tabular}{|c|c|c|c|c|c|c|}
\hline \multirow[b]{2}{*}{ Variables } & \multirow[b]{2}{*}{ Sample } & \multicolumn{5}{|c|}{ Eating attitude domains } \\
\hline & & Dieting & $\begin{array}{c}\text { Oral } \\
\text { control } \\
\text { \&bulimia }\end{array}$ & $\begin{array}{c}\text { Food } \\
\text { preoccupation }\end{array}$ & Purging & $\begin{array}{l}\text { Total eating } \\
\text { attitude test }\end{array}$ \\
\hline \multirow{2}{*}{$\begin{array}{c}\text { Sex } \\
\text { (mean rank) }\end{array}$} & male & 255.2 & 255.3 & 230.5 & 221.0 & 239.2 \\
\hline & female & 239.8 & 239.7 & 267.9 & 278.6 & 258.1 \\
\hline \multicolumn{2}{|l|}{ P-value } & 0.22 & 0.22 & 0.003* & $0.001 *$ & 0.14 \\
\hline \multirow{2}{*}{$\begin{array}{c}\text { Grade } \\
\text { (mean rank) }\end{array}$} & first & 260.1 & 246.9 & 257.8 & 257.5 & 260.5 \\
\hline & fourth & 235.4 & 249.1 & 238.3 & 238.6 & 235.6 \\
\hline \multicolumn{2}{|l|}{$P$-value } & $0.04 *$ & 0.86 & 0.12 & 0.13 & 0.05 \\
\hline \multirow{2}{*}{$\begin{array}{c}\text { Faculties } \\
\text { (mean rank) }\end{array}$} & practical & 229.7 & 258.9 & 232.2 & 245.5 & 239.0 \\
\hline & Non-practical & 254.3 & 244.2 & 253.4 & 248.8 & 251.1 \\
\hline \multicolumn{2}{|l|}{ P-value } & 0.09 & 0.31 & 0.15 & 0.81 & 0.41 \\
\hline \multirow{2}{*}{$\begin{array}{c}\text { BMI } \\
\text { (mean rank) }\end{array}$} & Normal weight & 246.6 & 224.3 & 246.6 & 250.5 & 240.2 \\
\hline & Over weight & 231.9 & 289.0 & 231.9 & 222.1 & 248.5 \\
\hline \multicolumn{2}{|l|}{ P-value } & 0.29 & $0.001 *$ & 0.29 & 0.37 & 0.57 \\
\hline
\end{tabular}

$*$ Statistically Significant $p<0.05$ 
Table (5): Total mean rank score of body shape questionnaire according to personal and physical characteristics of the studied university students, El-Minia university, $2011(n=495)$.

\begin{tabular}{|c|c|c|c|c|c|c|}
\hline \multirow[b]{2}{*}{ Variables } & \multirow[b]{2}{*}{ Sample } & \multicolumn{5}{|c|}{ Body shape questionnaire domains } \\
\hline & & $\begin{array}{c}\text { Others } \\
\text { opinions }\end{array}$ & $\begin{array}{c}\text { Body shape } \\
\text { Dissatisfaction }\end{array}$ & $\begin{array}{l}\text { Body shape } \\
\text { anxiousness }\end{array}$ & $\begin{array}{c}\text { Feeling } \\
\text { over } \\
\text { weight }\end{array}$ & $\begin{array}{l}\text { total Body } \\
\text { shape }\end{array}$ \\
\hline \multirow{2}{*}{$\begin{array}{c}\text { Sex } \\
\text { (mean rank) }\end{array}$} & Male & 244.1 & 243.2 & 225.0 & 233.5 & 235.9 \\
\hline & female & 252.4 & 253.5 & 274.0 & 264.5 & 261.7 \\
\hline \multicolumn{2}{|l|}{ P-value } & 0.51 & 0.41 & 0.001* & 0.01* & 0.04* \\
\hline \multirow{2}{*}{$\begin{array}{c}\text { Grade } \\
\text { (mean rank) }\end{array}$} & first & 252.4 & 249.7 & 249.5 & 253.3 & 251.6 \\
\hline & fourth & 243.6 & 246.3 & 246.6 & 242.7 & 244.4 \\
\hline \multicolumn{2}{|l|}{ P-value } & 0.49 & 0.79 & 0.82 & 0.39 & 0.57 \\
\hline \multirow{2}{*}{$\begin{array}{c}\text { Faculties } \\
\text { (mean rank) }\end{array}$} & practical & 244.1 & 233 & 251.5 & 232.5 & 249.2 \\
\hline & Non-practical & 249.3 & 253.2 & 246.7 & 253.4 & 247.6 \\
\hline \multicolumn{2}{|l|}{ P-value } & 0.72 & 0.16 & 0.73 & 0.14 & 0.91 \\
\hline \multirow{2}{*}{$\begin{array}{c}\text { BMI } \\
\text { (mean rank) }\end{array}$} & $\begin{array}{l}\text { Normal } \\
\text { weight }\end{array}$ & 260 & 257.8 & 256.3 & 242.6 & 252.6 \\
\hline & Over weight & 197.8 & 203.8 & 207.2 & 242.2 & 216.8 \\
\hline \multicolumn{2}{|l|}{ P-value } & 0.001* & 0.001* & 0.001* & 0.98 & $0.01 *$ \\
\hline
\end{tabular}

* Statistically Significant $p<0.05$

Table (1) describes the distribution of the studied students regarding their personal and physical characteristics. It was observed that $(97.2 \%)$ of first grade students aged between (18-20 years) and less than half $(46.6 \%)$ of fourth grade students aged between (21-26 years). The majority of first grade $(83 \%)$ and fourth grade students $(69.5 \%)$ have normal BMI. Participation of males in first grade more than females $(56.9 \%)$; however participation of females in fourth grade more than males $(50.6 \%)$.

Figure (1) shows that the majority of male and female students have normal weight.

Table (2) reveals the relation between the students' responses to body figure rating scale and their sex. It was observed that there were a statistically significant differences between males and females in "ideal wished shape and the shape that it is attract the opposite sex" males were chose "below average figure" with ( $\mathrm{p}=0.001,0.001$ respectively).

Table (3) shows the distribution of the studied students regarding their response to their body figure scale in relation to their BMI. It was observed that, there were statistically significant differences between BMI and the current shape items ( $p=0.001$ ). And there were no significant difference in relation to the others items.

Table (4) the above table clarified that females were significantly more preoccupied with food than males $(p=0.003)$, females were significantly more purging than males $(\mathrm{p}=0.001)$. First grade have significantly more dieting behavior than fourth grade $(\mathrm{p}=0.04)$. No statistically significantly between practical and non practical faculties among eating attitude domains. Overweight students have significantly more oral control and bulimia than normal weight students ( $\mathrm{p}=0.001)$.

Table (5) as shown in the above table, females have significantly more body shape anxiousness than males $(p=0.001)$, females have significantly more feeling over weight than males $(p=0.01)$, females have significantly more body shape concern than males (0.04). No statistically significant difference between first and fourth grade in body shape domains score. No statistically significant difference between practical and non practical faculties in body shape domains score. Normal weight students have significantly more distress about Others' opinions than over weight students $(\mathrm{p}=0.001)$, normal weight students have significantly more dissatisfactions about the shape than over weight students ( $\mathrm{p}$-value $=0.001$ ), normal weight students have significantly more anxious about the body than over weight $(\mathrm{p}=$ $0.001)$

\section{Discussion:}

Body image defined as the thoughts, perceptions, feelings and beliefs associated with one's of his or her body (lowery et al., 2005).

A significant amount of pressure to be socially accepted is placed upon college students, in particular. Everyone looks a certain way, dresses in the same clothing and goes out to the same spots in town. Although it's not necessarily a stated face that 
going to college makes you more self-aware and selfconscious. The truth is that when you enter college, you are faced with a more subjective peer response, new lifestyle routines and new eating habits. Because of all these negligible factors, many students resort to binge dieting, unhealthy eating habits and hazardous health decisions (Celio et al., 2006).

In the present study revealed that approximately $80 \%$ of students were of normal weight and $11.7 \%$ were overweight and the reminders $6.7 \%$ were obese. This result is contradictory to that of Brunt et al., (2008), who indicated that approximately $27 \%$ of the students were overweight, and $8 \%$ were obese. Another $8 \%$ were underweight, and the remainders were of normal weight. Tamim et al., (2004) reported that in a sample of Lebanese college students, the rates of under weight and normal weight were $12 \%$ and $69 \%$, respectively. While the rates of obesity and overweight were $3 \%$ and $15 \%$, respectively.

Our findings showed that, $60.8 \%$ of females had normal weight, whereas $23.2 \%$ had overweight and $0.8 \%$ had obesity, (Figure 1). These results are contradict with those of Zivana (2010), who found that female adolescents aged 16-17 in all secondary schools in Banja Luka that $83.4 \%$ had normal weight, whereas $7.7 \%$ had underweight and $4.7 \%$ had obesity. This finding was consistent with that of Bayyari (2010), who studied BMI among female college students at Palestinian universities were $8.5 \%$ underweight, $77.3 \%$ were normal weight or average weight, $12.4 \%$ were overweight, and only $1.7 \%$ were obese.

Our results showed that students perceived their body weight status incorrectly according to their body mass index which normal and underweight students tended to perceive their current figure as "thin", while overweight students tended to perceive their selves as "average". These results are different from Khor et al (2009), who found that the majority of underweight, normal weight and overweight male and female subjects perceived their body weight status correctly according to their body mass index (BMI). This may be referred to college students are always looking for the ideal body weight, which may lead them to always wishing to change their weight. Culture, media play a role in thinks incorrectly perception of one's body shape.

Regarding selection of the figure that represented the ideal body shape that males were significantly more likely than females to select the "below average figure" to represent ideal wished shape $(\mathrm{p}=0.001)$. This contradicted Luevovasirikal (2007), who reported that males and females chose normal shape as the representative ideal shape. This study is confirmed on first year students at the University of Nottingham. Some students think that having a thin body is much more attractive to others of the opposite sex. This concept is usually built up by the media and culture of the community.

It was noticed from the present study that college students choose thin figure which represent about the current shape. These results are different from that of Forrest and Stuhldreher (2007), who found that college students describe their actual weight to be a lot heavier. The different between our results and that of Forrest and Stuhldreher may be referred to the difference between the Egyptian and American culture, where the students are concerned with their body shape and BMI earlier in their life.

Females had significantly higher purging behavior than males $(p=0.001)$. It seems that intense fear of gaining weight or becoming fat lead most of college females to engage in purging behaviors.

Our study showed that females had significantly higher food preoccupation score than males $(p=0.003)$. This confirms the fact that girls have knowledge about food types which increase or decrease the weight in order to maintain ideal weight more than boys, new independence related to the transition to college, young adults are faced with challenges of food selection and meal planning which may increased risk for weight gain.

Interestingly females were significantly feeling themselves as being overweight more likely than males $(p=0.01)$. These results are similar to that of (Unterhalter 2007) and Lemon et al., 2008), who reported that women were more likely to perceive themselves as being overweight than males. In other study Kiefer et al., (2000) stated that women tend to have a more "negative" attitude toward their bodies than males. The female desire to be thin is a critical factor in women's outlook toward their bodies and body image perception. This confirms that fatty females that huge bodies are less attractive. It is possible that they may have heard some ridiculous comments. The media direct their attention to maintain their physical fitness especially for girls through practical beauty programs or models competitions.

The present study revealed that, females had significantly higher body shape anxiousness score than males $(p=0.001)$. Such results are consistent with that of Yahia (2011), and Luevovasirikal (2007), who stated that females were worried about their body shape than males. This may be referred to females always consider them selves under others' observation and are being judged by their beauty and body shape. Some families direct their daughters to be concerned about their body shape which may represent a psychological pressure to them.

Our findings showed that, females had significantly higher total body shape questionnaire score (BSQ) 
$(\mathrm{p}=0.04)$. Such results are consistent with that of Yahia (2011), and Nichols et al., colleagues (2009), who found that females had significantly higher in BSQ scores than males $(\mathrm{p}=0.001)$. However, Khor et al., (2009), who found that the majority of both male and female adolescents were concerned with their body shape. Therefore, we conclude that there are many factors that could direct the girls to be concerned with their body shape such as; the transition from High Schools to the University, slimness has been fashionable, the public perception of slim women as attractive, desirable, and successful. More over, females are more concern with their body shape that affects their choosing their clothes, style, and uniforms. Parent, peers and social reinforcement are important factors in focusing on the thin ideal standard. At this stage, most females are prepared for building relationship with other sex; and they are considered that females as the source of beauty but males as the source of strength. Ivarsson et al., (2006) stated that boys had a more positive attitude to their appearance and to their weight than girls.

In the same regard we found that normal weight students had significantly higher body shape dissatisfaction and anxiousness score than overweight students $(p=0.001)$. Such results are consistent with that of Yeung et al., (2010), who found that normal and underweight students reported that they were dissatisfied with their appearance. But Forrest \& Stuhtdreher (2007) and Grossbard et al., (2011), found that both males and females with high body weight and body mass index were dissatisfaction with their body image. This may be referred to the fact that normal weight students like to maintain ideal weight and are afraid of weight gain and are always like to appear in front of the other sex in a better in their shape.

Our findings showed that normal weight students had significantly higher total body shape questionnaire score (BSQ) than overweight students $(p=0.01)$. Such results are contradict with that of Luevorasirikul (2007), who found that respondent with high body image concern were more likely to perceive themselves overweight. This may be explained normal weight students try to maintain their bodies from gaining weight, they prefer to have ideal weight. And always fear from disturbed body image that makes them more concerned to body shape.

\section{Conclusion:}

Based on the results of the present study, it was concluded that about more than half of participants have normal weight according BMI. We found that females were more concerned about their body shape more than males. Body shape concerns among females were associated with anxiousness, feeling overweight, and preoccupation with food and purging behavior.

\section{Recommendations:}

Based on the previous findings of the present study, the following recommendations are suggested:

- Health education programmes:

- Body image and their effect on psychological status of the students and how to deal with negative body image to avoid the risk of eating disorders.

- To teach students about the importance of eating variety of foods in well-balanced meals.

- To teach overweight students how to deal with their weight and teach to follow healthy manner in order to reduce their weight.

\section{References:}

1. Banfield SS and McCabe MP. (2002): An evaluation of the construct of body image. Adolescence. 37(146):373-393.

2. Barlett CP and Harris RJ. (2008): The impact of body emphasizing video games on body image concerns in men and women. Sex Roles. 59: 586-601.

3. Brunt etal., A, Rhee Y, Zhong Li. (2008): Differences in dietary patterns among college students according to body mass index. Journal of American Health. 56 (6):629-631.

4. Carling M. (2006): "Fast Food and Urban Living Standards in Medieval England" in Food and Eating in Medieval Barbie: pp. 27-51 Accessed 30 November 2011.

5. Celio CI, Luce KH, Bryson SW, Winzelberg AJ, Cunning D, Rockwell R. (2006): Use of diet pills and other dieting aids in a college population with high weight and shape concerns. International Journal of Eating Disorders. 39(6): 492-497

6. Centers for Disease Control and Prevention. Healthy weight. (2011): - it's not a diet, it's a lifestyle! Centers for Disease Control and prevention. http://www.cdc.gov/healthyweight/. Accessed March 29, 2012.

7. Cheung PC, Ip PL, Lam ST, Bibby H. (2007): A study on body weight perception and weight control behaviors among adolescents in Hong Kong. Hong Kong Med J. 13(1):16-21.

8. Cooper PJ, Taylor MJ, Cooper Z, Fairburn CG. (1986): The development and validation of the Body Shape Questionnaire. Int J Eat Disord. 6: 485-494.

9. Delinsky SS and Wilson GT. (2007): Weight gain, dietary restraint, and disordered eating in 
the freshman year of college. Eating Behaviors. 9: 82-90.

10. DiGioacchino RF, Sargent RG, Topping M. (2001): Body dissatisfaction among White and African American male and female college students. Eat Behav. 2(1):39-50.

11. Fallon A and Rozin P. (1985): Sex differences in perception of desirable body shape. Journal of Abnormal Psychology.49(1): 102-105.

12. Forrest $M$ and Stuhldreher W. (2007): Patterns and correlates of body image dissatisfaction and distortion among college students. American Journal of Health Studies. 22 (1):18-25.

13. Garner DM and Garfinkel PE. (1979): The eating attitude test; an index of the symptoms of anorexia. Psychological Medicine. 9: 273-279.

14. Garner DM, OLmsteal MP, Bohr Y, Garfinkel PE. (1982): the eating attitude test: Psychometric features and clinical correlates. Psychological Medicine. 12: 871-878.

15. Grossbard JR, Neighbors C, Larimer ME. (2011): Perceived norms of thinness and muscularity among college students: what do men and women really want? Eating Behaviors: an international Journal. 12 (3):129-9.

16. Hudson JI, Hiripi E, Pope Jr, Kessler RC. (2007): "The Prevalence and Correlates of Eating Disorders in the National Co morbidity Survey Replication". Biological Psychiatry. 61 (3): 348-358.

17. Ivarsson T, Svalander P, Litlere $\mathbf{O}$, Nevonen L. (2006): Weight concerns, body image, depression and anxiety in Swedish adolescents. Eating Behaviors. 7: 161-175.

18. Journal of the American Dietetic Association and Dietitians of Canada (2003): Vegetarian diets. 103(6): 748-65.

19. Khor GL, Zalilah MS, Phan YY, Ang M, Maznah B, Norimah AK. (2009): Perceptions of body image among Malaysian male and female adolescents Singapore Med J. 50(3):303311.

20. Kiefer I, Letiner B, Bauer R, Rieder A. (2000): body weight: the male and female perception. Social and preventive medicine. 45: 274-278.

21. Lowery SE, Kurpius SER, Befort C, Blanks EH, Sollenberger S, Nicpon MF. (2005): Body image, self-esteem, and health-related behaviors among male and female first year college students. Journal of College Student Development. 46(6):612-23.

22. Luevorasirikul K. (2007): Body image and weight management: young people, internet advertisement and pharmacists: part 2: A study of body image view and influences among first year university students. Doctor thesis, Nottingham university: 165- 187.

23. National Eating Disorders Association. (2001): what is going on with me? Seattle, WA: National Eating Disorder Association.

24. National Eating Disorders Association. (2005): Statistics: Eating disorders and their precursors. USA. http://www.nationaleatingdisorders.org.

25. Nichols SD, Dookeran SS, Ragbir KK, Dalrymple N. (2009): Body image perception and the risk of unhealthy behaviors among university students. West Indian Medical Journal. 58:14-18.

26. Sebastian, Rhonda S, Linda E, Cleveland, Joseph D, Goldman. (2008): Effect of Snacking Frequency on Adolescents' Dietary Intakes and Meeting National Recommendations. Journal of Adolescent Health: 503-511.

27. Sheild IV. (2004): Alteration in self concept: psychiatric mental health $2^{\text {nd }} e$, lippincott compeny:164.

28. Smith TG. (2004): The McDonald's equilibrium: Advertising, empty calories, and the endogenous determination of dietary preferences. Social Choice and Welfare. 23:383-413.

29. Unterhalter G, Farrel S, Mohr C. (2007): selective memory bias for words reflecting sexspecific bad image concerns. Eat. Behav. 8: 382389.

30. World Health Organization. (2006): BMI classification. World Health Organization. http://apps.who.int/bmi/. Accessed March 27, 2012.

31. Yahia N, El-Ghazale H, Achkar A, Rizk S. (2011): Dieting practices and body image perception among Lebanese university students. Asia Pac J Clin Nutr. 20 (1): 21-28.

32. Yeung W T L. (2010): Gender perspectives on adolescent eating behaviors: A study on the eating attitudes and behaviors of junior secondary students in Hong Kong. Journal of Nutrition Education and Behavior. 42 (4).

33. Zivana G. (2010): Body image among female adolescent. Curr Top Neurol Psychatr Relat Discip. 18 (2): 13-15. 